time, but occasionally requires the catheter. Less pain. Nail of thumb came off this morning. Considerable suppuration. Reduess near limit of burn. Remains on back all the time on account of puin in left side of polvis when he moves. Mental condition lunch better than before.

November 10th. Suppuration taking place. Lxcellent condition.

November 12th. Suppuration well marked; thumb all gangrenous. Ether operation by Dr. Cheever. Tissues divided and scruped away about the line of separation and the head of the first metacarpal bone sawn off. Opening irrigated. One stitch taken to bring parts togrether, and an iodoform ganze dressing applier. Urine normal, reaction ucid, specific gravity 1014, fuint trace of albumen. No blood or caste, few clumps of pus and bladder cells.

November 13th. Very easy after the operation. 'l'ook ether very well.

November 14th. 'The part is healthy, and shows vigorous granulations.

Novamber $15 \mathrm{th}$. Seems to have recovered entirely from tho electric shock. A new swathe affords relief, although his breathing is not very difficult without it. Looks well.

November 19th. General condition good. Breathing easy. 'Thumb doing well. No pain. Less tenderness in pelvis. Looks well.

November 23d. The opening at the thumb is clean and covered with bright granulations; the finger is also granulating, although the bone seems quite dead. Straight palmar splint applied to straighten finger.

November 27 th. 'The surfaces are granulating in a healthy way. Moderate discharge from the thumb stump. 'The bone on the posterior surface of the index finger seems to be covering over rapidly. General condition excellent. No more pain in the region of the pelvis. Discharged, relieved. The pulse and temperature were not remarkable. An effort to find this patient lately, proved unsuccessful, so I can say nothing of his subsequent condition. ('To be continuted.)

\section{A CASE OF OBSTRUC'TION OF THE COLON.1}

BY BKNJAMIN CUBHING, M.1).

Mis. M- age sixty-three, mother of six children. 'The first eight years of her married life she passed in India. More recently passed two years in India, whence she returned two yeurs ago. While in England, on her way home, she had an attuck of what she called "acute indigestion." On inquiry, I found that for want of conveniences, she had not, on her passage from Calcutta to London, been able to give proper care to have daily dejections. Soon after arriving home, she had a turn of colic, which was relieved by spirits of chloroform. Otherwise, her health has been generally good, or, at least, not such as to lead her to seek advice. Called herself " bilious," with sluggish bowels.

August 1st, she sent for me, saying, that having lately been constipated, passing only "suall, hard balls," she had taken a dose of custor oil, and, getting no result, had on the next day repeated the dose with the same want of success.

1 Read at the meeting of the Boston Socioty for Medical Improvement, February 24,1890 .
Symptoms: Pain in abdomen and slight nausea. No tenderness of abdomen, no distension. No tumor to be felt. No fever. Some peristaltic action. Could hear the gas occasionally pass along the intestine, but none from the rectum. I directed to give an enema, and relieve the pain by morphine per rectum. This gave a quiet night.

The next day (August 2d) patient fairly comfortable from effects of morphine given the night previous. I made a careful examination of the abdomen externally, and also examined per vaginam and rectum, but was unable to discover any tumor. 'The rectum was empty. Sulphate of magnesia, one ounce; water, one pint; gave a tablespoonful every hour. $\Lambda$ fter some hours this was rejected, and I gave ten grains of calomel, and repeated the same after waiting due time for effect of first dose. At the same time quieted any pain with suppositories of morphine and belladonnu. I also used massage from time to time. 'This treatment occupied four days. Liquid nourishment was given, but not enough being retuined to supply the patient's needs, I began with injections of beef tea and milk, each one ounce, and a teaspoonful of whiskey. These woro given regularly every two hours, day and night, until the end of the illuess.

August 7th. In the afternoon, with'a long tube, I gave un injection of glycerino. After a few hours, the patient's husband came to my office to say that the glycerine had done the work, and his wife was relieved. Next morning I found that she had passed a gool uight, but was again uneasy. 'That relief was but partial.

Same treatment, with ups and downs, until August $19 \mathrm{th}$, when I asked for consultation with Dr. Fitz, who accordingly visited her with me. I had thought that by tracing the colon, I could locate the obstruc. tion just above the sigmoid flexure. 'Tho patient was etherized, and Dr. Fitz was ablo to inject two quarts of warm water (or three pints?); no more. Up to this time the gas could be heard from time to time passing aloug the intestine. 'There was no tenderness of the bowels, although distended. 'There was no rise of temperature, no quickening of pulse, and she could take and retain (for the most part) liquid food. 'The question of making an artilicial anus was considered, but it was thought best to trust to general treatment.

On the 20th of $A$ ugust, through a rectal tube, with my Delefoy aspirnting syringe, $I$ pumped up air until tho patient compluined of distention. 'This 1 followed daily for a week, always with relief.

August $27 \mathrm{th}$, I first noted slight movement.

August 30th, gave enema of glycerine. This caused a great deal of pain, so severe that the usual suppository of morphine and belladonua did not give relief. I, therefore, gave a hypodermic of morphine. 'This was about $10 \mathrm{~A}$. M. 'The patient was quite sleepy all the day and following night, and the next morning had $u$ good stool of the consistence of thick hasty pudding, and in amount what would be large for oue in heulth.

She had, after this, a movement each morning which came in part, at least from above the seat of obstruction, as proved by the fruit seeds in it. 'This continued until September 8th, when an enema of castor oil and borax (to make an emulsion), a suppository and Hunyadi Water were given with a good result. 'This to the 12th, with a good stool, some days two or three. At this time the abdomen, which had been 
much distended, returned to its natural size. Raw oyster's were taken with a good appetite. Other food, such as jellies, was taken; and all looked favorable.

September 28th, stools less frequent, and distention distressing. I aspirated in the coecum, with complete relief. 'This was at 9 P. M. Good night's rest; and next morning a good stool, containing lumps, one as large around as an English walnut, and somewhat longer.

October 1st, movement.

October 4th, sulphate of soda, Hunyadi being disagreeable.

October 5th, sulphate of soda.

October 6th, sulphate of soda, aspirated six or seven times.

October 10th, died suddenly, after an illness with very little pain for such a case. Duration, ten weeks.

Autopsy. - The surface of the intestines was covered with thin facal matter, which oozed from a small pin-hole on the posterior part of the colon. Had it been anterior, I might have thought it made by the aspirator: Colon and cocum largely distended. Emptied in two slop-puils, and by estimation there was something over a water-pail full. No lumps. 'The obstruction was in the descending colon, about on a level with the brim of the pelvis. No infiltration nor adhesions.

'Ihese cases of obstruction, always of practical interest, are now especially so, since such advance has been made in abdominal surgery. The question of surgical measures will always come up, each case to be decided on its own conditions. It is unfortunate that an exact diognosis cun rarely be made in the beginning. In this case I felt quite sure that there was no strangula. tion, either by twist or band; at any rate, that the intestine was not absolutely impervious; that it was an arrest of facal matter, either from sluggish bowels or annular stricture, probably the latter. If the first, the treatment was clear to my mind. If the latter, I had hope, referring to my experience in such cases, to give relief for a time, without operation. As to treatment (non-surgical), I should rely on liquifying the faces by small and repeated doses of saline solution, on opiates and on enemas. There is generally strong pressure by friends, too often supported by injudicious consultants, for the use of drastic purgatives; a pressure which the young practitioner finds it hard to withstand. Neither would I rely solely on enemas.

With regard to surgicul measures, I should not feel that 1 had done my patient any great service by adding a few months to life, at the expense of an artificial anus, however, I might feel it my duty to do so if this were the only chance. If I could remove the cause, this would indeed be worth a great risk.

Thinking over the case, and somo others in which I have made autopsies, this question occurs to me, which I should like to have answered by those whose experience is larger than mine. In all cases in which the diagnosis of annular stricture above the sigmoid fiexure cun be made with reasonable certainty, ought it not to be the rule to make an exploratory operation, with a view to resection of the intestine?

- The removal of the "isis" from a patient blind from "glancoma," is an operation described by a daily paper.
EX'TRAC'TION OF A FRAGMEN'T OF IRON FROM 'THE INTERIOR OF 'THE EYE BY MEANS OF 'TUE ELEC'TRO-MAGNEI' PROBABIE RECOVERY.

HY HASKE'T DEISY, M.D.

IN former times the penetration of a forcign body into the vitreous humor entailed substantially the loss of the eye, in many cases indeed necessitated its removal in order to prevent sympathetic inflammation of its fellow. Even when the media remained sufficiently clear to allow a positive diagnosis by means of the ophthalmoscope, the use of the forceps, introduced in to the interior of the eye, was likely to bring about destructive inflammation. Since the invention of the electro-magnet, as well as the adoption of antiseptic precautions, these cases are no longer hopeless. In an appreciable number of those thus treated (one set of statistics gives sixteen per cent) normal vision is retained. Where the operation is less successful, useful vision may be hoped for, and finally, in mauy instances, the eye-ball, though sightless, is preserved; a fairly natural appearance being retained.

One of the more recent monographs ${ }^{1}$ on this subject furnishes an instructive, although not a brilliant, series of results. Out of twelve cases where the irou had penetrated the interior of the eye, the magnet grasped and extracted in soven. One eye gained normal vision; one eye gained useful vision; one eye gained a faint perception of objects : four eyes were lost (removal of two of these advised).

Cases of complete success are therefore somewhat rare; and as the operation itself is not one of every day occurrence, I feel the less hesitation in reporting the following history.

J. P. C., aged twenty-nine, a blacksmith in the employ of the Old Colony Railroad Company, was struck in the right eye, January 27,1890 , by a piece of iron which thew from an anvil on which he was hammering. Vision was immediately obscured and work had to be suspended. He remained at home, but suffered no pain until February 4th, when an attack of great severity came on and lasted twenty-four hours, during which time he was unable to bear a ray of light with either eye. He had gone the rounds of the hospitals but, to judge from his account, no positive diagnosis had been made, and no definite treatment advised. I saw him February 10th. The eye presented a normal appearance, save for an artificially dilated pupil and a raised, reddish patch, some six millimetres in diameter, situated on the eye-ball midway between the edge of the cornea and the outer commissure of the lids. No wound of the globe could be discovered. Vision 2-10. I should here mention that there was irregular astigmatism of the other eye, and that its vision was but 4-10. 'The ophthalmoscope showed many floating streamers of coagulated blood in the vitreous, their presence rendering examination of the fundus oculi exceedingly difficult. 'The nerve was dimly visible and appeared normal. On two occasions, when the eye was rapidly raised and as rapidly lowered, I made out a gleaming opaque body, of small size, that rose a short distance from the bottom of the eye, on the right side, and immediately fell back again.

An operation was proposed and at once acquiesced

- Carl Mollinger : Uber ifo Magnot-Jixtraotionen all der baslor Ophthalmologischen Klinik. 1887. 